\title{
A Typological Suggestion Concerning Hellenistic and Roman LYCIAN SARCOPHAGI
}

\author{
HELLENISTIKK VE ROMA DÖNEMİ LYKIA LAHİTLERİ ÜZERİNE \\ TIPOLOJIKK BİR ÖNERME
}

\author{
ELIF ÖZER*
}

\begin{abstract}
The typological studies of Lycian tombs began in the eighteenth century. Although these pioneer typologies were not satisfactory, studies continued in subsequent years. Akurgal divided them into three groups and put all the Lycian sarcophagi in the second group in his typology. But he does not distinguish the differences between these sarcophagi. In addition, the second group is also termed: 'The Monuments of Tombs in the Tradition of Native Anatolia". This terminology contradicts the characteristics of these sarcophagi, as Lycian sarcophagi reflect not only native Anatolian traditions; but also influences from Greek, Persian and Roman art. In the 1970's, Borchhardt created a new typology that was more detailed. Subsequently Atila, İdil and İskan-Y1lmaz attempted new typologies. This study is a continuation from these typologies. In this typology study, before all else the attempt was made to understand the sarcophagi in Lycia during the problematic Hellenistic and Roman periods. From my previous studies elsewhere in Lycia, these sarcophagi can be divided into 5 distinct types.
\end{abstract}

Keywords: Lycia • Sarcophagus • Typology • Rome • Hellenistic
Öz: Lykia mezarları tipolojisi 18. yüzyıldan itibaren çalışılan bir alan olmakla birlikte, erken dönem araştırmaları çok yeterli değildir. Akurgal tarafından yapılan araştırmada üç grupta incelenen Lykia mezarları içinde lahitler ikinci gruba alınmış ancak aralarındaki farklılıklar değerlendirilmemiştir. Akurgal, ikinci gruba yerleştirdiği mezarların tamamını "Yerli Anadolu Geleneğini Sürdüren Mezar Anıtları” olarak tanımlamış ancak, Lykia lahitlerinin sadece yerli Anadolu geleneğini değil, Hellen, Pers ve Roma etkilerini de taşıdığı göz ardı edilmiştir. 1970'lerden itibaren Borchhardt, Atila, İdil ve Yılmaz tarafından Lykia lahitleri üzerine tipoloji çalışmaları gerçekleştirilmiştir. Bu çalışmada ise tüm bu çalışmaların hem devamı hem de -şimdilikson noktasını oluşturmaktadır. Bu çalışmada Lykia Bölgesi'nin Hellenistik ve Roma Dönemleri lahitleri ele alınmış ve hangi tipin ne zaman başlayıp hangi döneme kadar devam ettiği araştırılmıştır. Şimdiye kadarli öncül çalışmalarımdan Lykia'nın farklı yerlerinde bu tarz lahitler 5 farklı gruba ayrilabilmektedir.

Anahtar Kelimeler: Likya • Lahit • Tipoloji • Roma • Hellenistik

The dominant tomb art of Lycia began in the $\mathrm{VI}^{\text {th }}$ c. B.C. and continued into the Roman imperial period $^{1}$. The tombs of Lycia fall into four broad categories: pillar tombs, heroon tombs, sarcophagi and rock-cut tombs. Although sarcophagi are one of the most common forms of tombs in antiquity, the Lycian type is quite distinctive. Generally it consists of four parts; a base, very common; a second grave-chamber (hyposorion) that was destined for the owner's slave or dependants; a chest for the tomb owners, which was closed with a crested - "Gothic" lid".

There were three main influences on the form of these tombs: the local, the Near Eastern and the

* Prof. Dr., Pamukkale Üniversitesi, Arkeoloji Bölümü, Denizli. eozer@pau.edu.tr

1 İdil 1993; Uğurlu 1999; 2003, 355-66.

2 Kjeldsen - Zahle 1975, 335. 
Greek. In the earlier period pillar tombs form a grave type, found particularly in West and Central Lycia, tombs that were generally erected for local dynasts. Although having a votive characteristic, these also carry a public and a propagandists meaning.

The typological studies of Lycian tombs began in the $18^{\text {th }} \mathrm{c}^{3}$. Although these pioneer typologies were not satisfactory, studies continued over subsequent centuries. Akurgal has divided them into three groups and put all Lycian sarcophagi in the second group of his typology ${ }^{4}$. But he did not clarify the differences between these sarcophagi. In addition, the second group is also termed, 'Monumental Tombs in the Native Anatolian Tradition' yet this term is contradicted by the characteristics of these sarcophagi. This is because Lycian sarcophagi reflect not only native Anatolian traditions but also influences from Greek, Persian and Roman art.

In the 1970's, Borchhardt created a new typology that was more detailed in comparison with the former typology ${ }^{5}$. The Lycian tombs are divided by Borchhardt into two main groups, the 'free' and the 'rock-cut' tombs. By considering the differences in their forms he divided the first group into five sub-groups. The sarcophagi are put into the IV. and V. sub-groups. The form of double tombs found in the earlier sarcophagi of the region are put in the V. group. Although the IV. group is divided into three sub-groups, I consider that this classification is not adequate for the variety of sarcophagi types in Lycia.

Borchhardt placed ".... The sarcophagi, which consist of the gothic lid and the construction of a frame band..." in the IV a, group. The matter of how the chest and hyposorion was formed is not mentioned in the classification but is considered only for the form of the lid. The detailed analysis of the lid is the most important part in establishing the typology of Lycian sarcophagi. However, the forms of the tabula ansate, hyposorion and podium are also important. If we attempt to place the sarcophagi in a certain period from the shape of lid according to Borchhardt's IVa group; we could place this lid form in every period. The source for this idea comes from the necessity of analyzing the lids which have a frame band. As the frame band form and imitation wooden construction on sarcophagi lids can be found from the $\mathrm{IV}^{\text {th }} \mathrm{c}$. B.C. to the $\mathrm{II}^{\text {nd }}$ c. A.D.

For example, the sarcophagus that is dated to the $\operatorname{II}^{\text {nd }}$ c. B.C. in Trysa and the sarcophagi of Cyaneai were produced between the end of the Hellenistic period and the $\operatorname{IId}^{\text {nd }}$ c. A.D., while the sarcophagus from Antiphellos was produced in the $\mathrm{IV}^{\mathrm{th}}$ c. B.C. ${ }^{6}$.

The detailed analyses of the chests and the sub-structure of the sarcophagi from Trysa, Cyaneai, Antiphellos and the other cities are dated from the $\mathrm{IV}^{\text {th }}$ c. B.C. to the $\mathrm{II}^{\text {nd }}$ c. A.D. result in many disparities, both from the lids and the other parts of the sarcophagi. The chest of the Antiphellos sarcophagus was formed through reflecting wooden construction in the stone. The narrow and long panels were positioned on the front face of the chest. Hyposorion were created from a solid block.

The sarcophagi which are dated to the Hellenistic period and the other chests dated to the Roman period from Trysa were not produced with stone planks like the examples from the $\mathrm{IV}^{\text {th }} \mathrm{c}$. B.C. The narrow panels that traditionally belonged to the $\mathrm{IV}^{\mathrm{th}} \mathrm{c}$. B.C. were continued in the Hellenistic period. However, the width of these panels began to increase and semicircles were

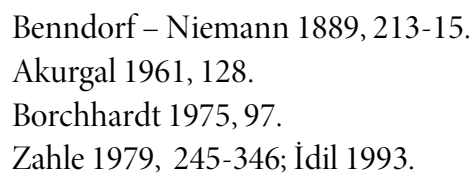


depicted on the upper edges, and finally reached the form of the Roman tabula ansate. It is impossible to place these sarcophagi within Borchhardt's Type IVa, as neither their forms nor chronology with this information complies with this typology. Also, Borchhardt's Types IVb and IVc do not provide a satisfactory classification for Lycian sarcophagi due to the variety of forms. Because the sarcophagi that have only a gothic lid and chest forms are evaluated in IVb, and only those with hyposorion in the IVc groups, whereas there are many sarcophagi formed with a gothic lid and chest form. It is difficult to understand from which data this typology of Borchhardt is supported. If the Lycia lid is important for creating the type, which details are required as a type to separate it from IVa. We could make the same comment in respect to sarcophagi with hyposorion. I suggest that the IV. Group typology of Borchhardt is not of much use in the dating of Lycian sarcophagi. If IVb group is intended for the sarcophagi that consist of only lid and chest without substructure (hyposorion and podium), as both hyposorion and/or podium were used in the $\mathrm{IV}^{\text {th }} \mathrm{c}$. B.C., the most appropriate dating extends from the Hellenistic into the Roman period. The date for Group IVc, namely examples with hyposorion, extends from the earlier period into the III ${ }^{\text {rd }}$ c. A.D. The dating indicated from this typology is far from being any help for us.

Subsequently, Atila, İdil and İskan-Yılmaz attempted to provide new typologies ${ }^{7}$. The studies of İdil and Atila were based upon the typology of Borchhardt; but, in addition, they increased the diversity of forms of the sarcophagi, by also trying to provide a classification according to the ornament that was employed. Although the typologies of Atila and İdil can be evaluated as an advance, in comparison with Borchhardt's typology, it was not an attempt to provide from the typology the chronological placement. The question therefore remains, when did types of sarcophagi began; how were they continued and how some forms or ornament were lost or retained during the Hellenistic and Roman periods? İskan-Yllmaz, Chief of Patara Excavations, produced a new typology that divided the sarcophagi into four groups. As the latest attempt to provide a better typology, İskan-Yllmaz aimed to consider the chronological sequence of the forms, but arranged a simple chronological typology.

Despite their success in detailing forms, there are some problems with this typology. In their first group, Lycian types are included with relief and imitated wooden construction from the Classical period; after this one expects to find the Hellenistic sarcophagi according to the chronology, however, the Roman sarcophagi, with grave chamber or only podium without grave chamber follow.

Despite hyposorion, the sarcophagi with podiums without a grave chamber were continued in her second group, which caused another paradox in her suggestion for Roman sarcophagi. It is hard to agree with her suggestion, as there are examples of sarcophagi with inscriptions that have hyposorion dating from the Roman period, a sarcophagus with hyposorion was found at Olympos ${ }^{8}$ dated in the $\mathrm{II}^{\text {nd }}$ c. A.D. and many sarcophagi with hyposorion, which also have the triangular pediment and Lycian type lids in Cyaneai ${ }^{9}$, Andriace (İdil, 1993) and in other cities ${ }^{10}$ have been found. There are also some problems with the third and the fourth typological groups of İskanYılmaz. The third group is described by İskan-Yılmaz thus: 'Lycia lid is in a majority and gradually

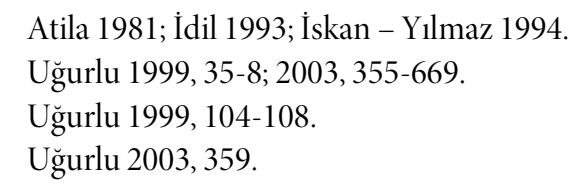


acquired circle and low form ${ }^{\prime 11}$. The sarcophagi in question were produced in the Roman period and also confirm, with the Cyaneai sarcophagi, that the form of the gothic lid was lowered in the Roman age. In my opinion including the sarcophagi with a triangular pediment in the same group caused more chaos in defining the types of sarcophagi. The triangular pedimented sarcophagi were also produced, like the low Lycia lids during the Roman period, but they are discrete from each other in form, hence surely they should be placed within a different category. Further, the Hellenistic sarcophagi are placed in İskan's fourth group, however, emphasizing the number of the Hellenistic sarcophagi and there are many problems that should be explicated as the Hellenistic sarcophagi are not distinguished through their lids and substructures in her typology.

\section{Suggesting A New Typology}

My own study ${ }^{12}$ forms a continuation from these typologies. According to the Cyaneai sarcophagi, classified into two categories from the ornaments and the forms of the sarcophagi, and 5 main groups and 13 subgroups of forms were made in my previous study. But then a simple typology was preferred, with the subgroups removed in the article concerning the Andriace sarcophagi, ${ }^{13}$ in consequence of the fact that greater attention was paid to the details distracted from the primary aim. The primary aim of this typology is the attempt to understand the problematic of Lycian sarcophagi of the Hellenistic and Roman periods.

According to my previous studies in Lycia, these sarcophagi could be basically divided into five distinct types (fig. 1):

Type I:

Lycian lid. There are lion heads or cubic formed projecting parts (used to lift the lids) on the long sides. The short sides are separated with a band of frame and a lion protome underneath or the projecting part of the half circle is carved. There are long narrow panels for inscriptions on the long sides of the chests. We generally see the lion's paws or spherical parts on the hyposorion and podium. This type starts from the Hellenistic period and continues to the early $\mathrm{I}^{\text {st }}$ c. A.D. and decreases from the middle of the II ${ }^{\text {nd }}$ c. A.D. (fig. 2).

Type II:

Lycian lid. The cubic or hemispherical projecting parts are carved on the long sides of the lid (fig. 3). The short sides of the lid are usually similar to Type 1, but sometimes don't carry the frame band motif. There are usually tabula ansate on the long sides of the chests. The hyposorion and podium are sometimes carved from the rock. Like the Type I, a sitting-bench with lion's paw also appears, but is uncommon. This type seems to appear in the early $\mathrm{I}^{\text {st }} \mathrm{c}$. A.D. and was continuously employed until the end of $\mathrm{II}^{\text {nd }}$ c. A.D. Examples from the $\mathrm{III}^{\mathrm{rd}}$ c. A.D. are rare.

Type III:

Lycian lid (fig. 4). There are hemispherical projecting parts on the long and short sides of the lids. Sometimes we find lion and Medusa heads employed in these positions instead of the projecting parts. On the chests there are tabula ansate. The hyposorion and podium resemble Type I and II, however, sometimes they do not exist and chamosorion sarcophagi are also found within this type.

\footnotetext{
11 İșkan - Yılmaz 1994, n. 8, 45-48.

12 Uğurlu 1999.

13 Uğurlu 2003, 355.
} 

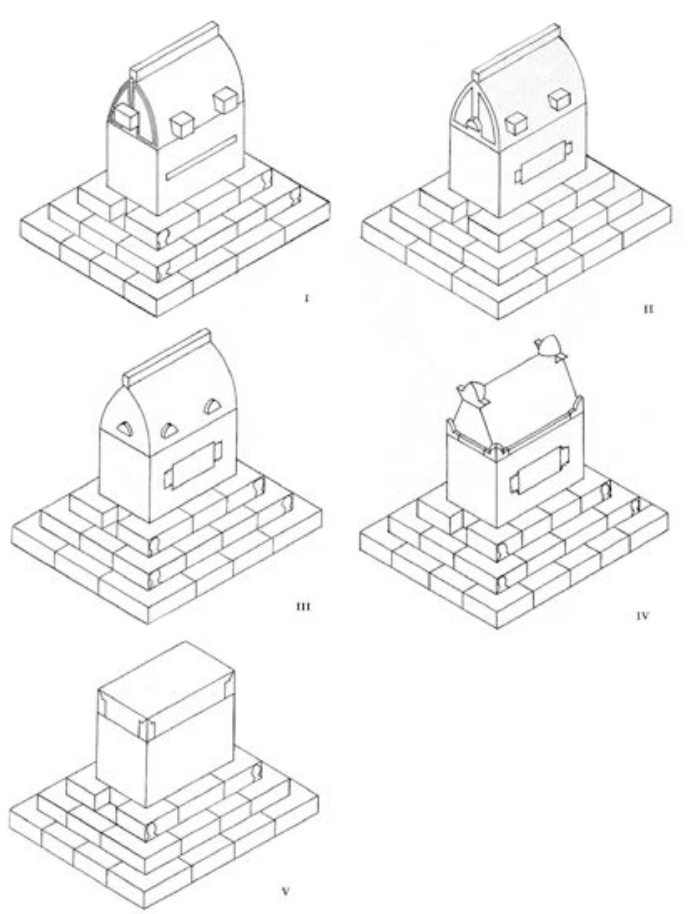

Fig. 1. The Typology of Lycian Sarcophagi: Top Left: Type I, Lycian lid. Top Right: Type II, Lycian lid. Centre Left: Type III, Lycian lid. Centre Right: Type IV, Triangular lid in the shape of a pediment with acroteria. Bottom Left: Type V, Monolithic flat lid.

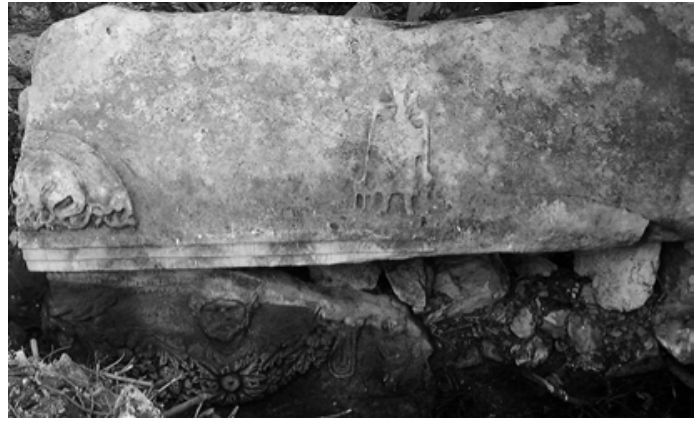

Fig. 5. The Sarcophagus from Olympos

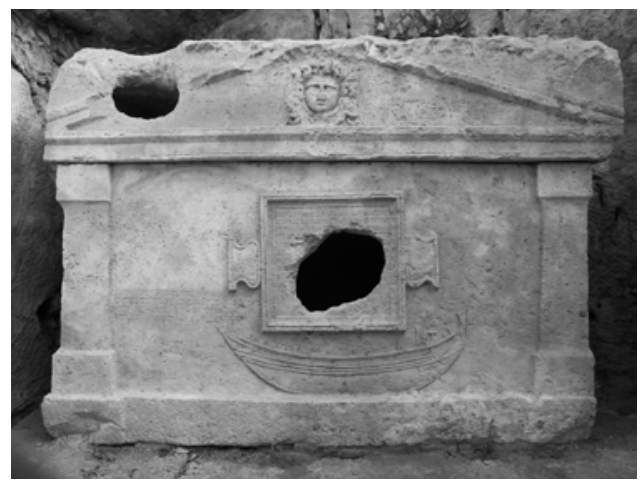

Fig. 6. The captain Eudemos's Sarcophagus from Olympos

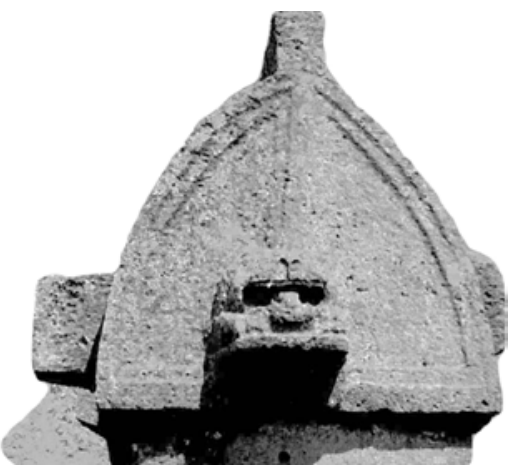

Fig. 2. The Lycia lid and lion protome from Cyaneai

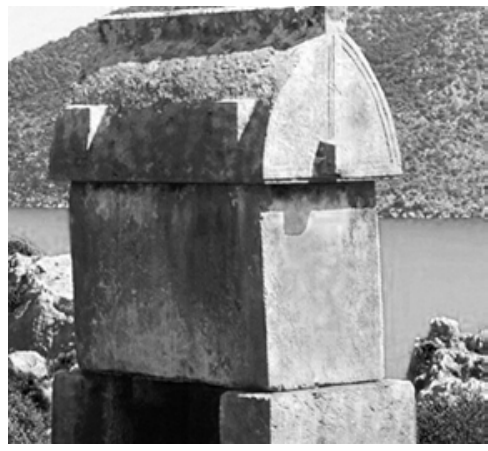

Fig. 3. The Lycia Sarcophagus from Simena

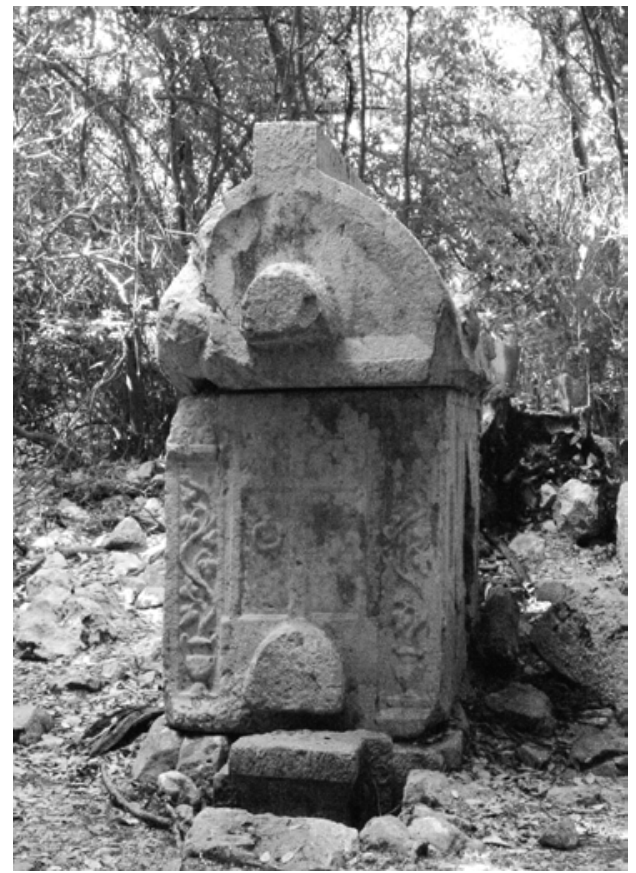

Fig. 4. The Lycia Sarcophagus with Pilasters 
These begin at the end of the $\mathrm{I}^{\mathrm{st}} \mathrm{c}$. A.D. and early examples are uncommon. Between the middle and end of the $\mathrm{II}^{\text {nd }} \mathrm{c}$. A.D. the numbers of this type increase. In the $\mathrm{III}^{\mathrm{rd}} \mathrm{c}$. A.D. it was continued but was not produced as frequently as Type IV.

Type IV:

Triangular pediment lid with acroteria (fig. 5). The heights of the lids are usually low. There are lion protomes, medusa heads or hemispherical projecting parts on the short sides. The chests have a tabula ansate. The hyposorion and podium are similar to the other types. The dating for Type IV is between the end of the II ${ }^{\text {nd }}$ and the III ${ }^{\text {rd }}$ c. A.D.

Type V:

Monolith, flat lid (fig. 6). It is decorated on the corners with acroteria, which are usually stylized. There are small, cubic projecting parts and rarely, lion protomes or Medusa heads on the short sides. Tabula ansate appear on the chests. The hyposorions or podiums are often carved as a sittingbench or are rock-cut. The date of this type is similar to that for Type IV.

\section{Conclusion}

To confirm the basic point of the chronology whether alteration continued or not, and according to the results we reached, the problem is solved. The earlier Lycian sarcophagi are not involved in this typology, because we think these examples are solved by Borchhardt's Type V. Below a simple catalogue is provided with this new typology for Lycian sarcophagi, benefiting from İdil's catalogue and providing a suggestion as to new dating for Lycian sarcophagi related to this new typology.

\begin{tabular}{|c|c|c|}
\hline Type I & & \\
\hline City & Ornament & Date \\
\hline Buyuk Avsar & Lion heads, shield motive. & Hellenistic (Sanlı 1996, 171-2, 181). \\
\hline Cyaneai & $\begin{array}{l}\text { Lion and bull heads, shield, } \\
\text { mask, wreath, rosette, portrait } \\
\text { bust, mythological figures (eg. } \\
\text { Heracles). }\end{array}$ & $\begin{array}{l}\text { There are fifteen sarcophagi of Type I in Cyaneai. } \\
\text { These have been dated to between the Hellenistic } \\
\text { and the } \mathrm{I}^{\text {st }} \text { c. A.D. in the studies of Ugurlu (Uğurlu } \\
\text { 1999, 38, 44, 51, 63-70, Kat. 1-2, 12, 27,31, 47-9, } \\
\text { 51-8, 78). Kat. 27, dated to between the } \\
\text { Hellenistic and the beginning of the } \text { It }^{\text {st }} \text {. A.D. by } \\
\text { Ugurlu (Uğurlu 1999, 69), but by İdil to the IV } V^{\text {th }} \text { c. } \\
\text { B.C., seems more appropriate (İdil 1993, 14, 41, } \\
\text { Kat. 3). However, Borchhardt-Neumann have } \\
\text { suggested the Hellenistic period for this } \\
\text { sarcophagus (Borchhardt- Neumann 1997, 63- } \\
74,73, \text { n. 38). For Kat. } 54 \text { of Ugurlu, İdil suggested } \\
\text { the Roman period (İdil 1993, 15); Borchhardt- } \\
\text { Neumann gives it to the Hellenistic (Borchhardt- } \\
\text { Neumann 1997, 73, n. 39). }\end{array}$ \\
\hline Trysa & $\begin{array}{l}\text { Medusa, bull and lions heads, } \\
\text { dolphins, Quadriaga, wreath, a } \\
\text { male figure, sitting on a goose, a } \\
\text { man wearing a chiton and hold- }\end{array}$ & $\begin{array}{l}\text { Hellenistic (İdil 1993, Kat. 2, Lev. 84. 1-2). (II }{ }^{\text {nd }} \text { c. } \\
\text { B.C.). Late Hellenistic (Kleiner 1957, 1-10, } 3 \text {, } \\
\text { Taf. 1; Bean 1997, 116). In my opinion it dates } \\
\text { from the Hellenistic period (Pl. III, 2). }\end{array}$ \\
\hline
\end{tabular}




\begin{tabular}{|c|c|c|}
\hline & $\begin{array}{l}\text { ing a spear and beside him a } \\
\text { woman, four men with shields } \\
\text { and a cavalier were depicted on } \\
\text { the ridgepole. The masks are on } \\
\text { the edges of the ridgepole. Nar- } \\
\text { row panels on the chest. The } \\
\text { garland and bucranions on the } \\
\text { panel of the chest. Palmet and } \\
\text { omphalos on the panel of the } \\
\text { short side of the chest. }\end{array}$ & \\
\hline Sura & Lion protomes, portrait bust. & $\begin{array}{l}\text { There are three sarcophagi of Type I. İdil, } \\
\text { suggested the Roman period (İdil 1993, 68; Kat. } \\
2,4,5 \text { ); but we assume they date from the Late } \\
\text { Hellenistic to the beginning of the It c. A.D. } \\
\text { (Uğurlu } 1999,64),(P I . I V, 1) \text {. }\end{array}$ \\
\hline Phellos & Simple. & $\begin{array}{l}\text { There are five sarcophagi of Type I. Three are } \\
\text { dated to the } \mathrm{IV}^{\mathrm{th}} \text { or III }{ }^{\mathrm{rd}} \text { c. B.C. by İdil (İdil 1993, } \\
58 \text {, Kat. 2-4). The others to the Early Roman } \\
\text { Period (İdil 1993, Kat. } 5 \text { A-B). The dates of the } \\
\text { last two should be between the Hellenistic and the } \\
\text { beginning of the It } \text { c. A.D. included in Type I. }\end{array}$ \\
\hline Teimussa & Bull head, Lion protomes Shield. & $\begin{array}{l}\text { There are three sarcophagi of Type I. İdil dates } \\
\text { them to the Roman Period (İdil 1993, 70, Cat. 1- } \\
\text { 3; Bean 1997, 116). We date them to between the } \\
\text { Late Hellenistic (Uğurlu 1999, 67) and the } \\
\text { beginning of the It c. A.D. (Pl. IV, 2). }\end{array}$ \\
\hline Antiphellos & Simple. & Hellenistic (İdil, 1993, 27, Kat. 2). \\
\hline Hoyran & $\begin{array}{l}\text { Lion and bull heads, women } \\
\text { portrait bust. }\end{array}$ & $\begin{array}{l}\text { There are two sarcophagi of Type I, dated to the } \\
\text { IV }^{\text {th }}-\text { III }^{\text {rd }} \text { c. B.C. (Levie 1982, 35; İdil 1993, } 34 \text {, } \\
\text { Kat. 1-2) In my opinion these are from the } \\
\text { Hellenistic period. }\end{array}$ \\
\hline Tlos & Simple. & $\begin{array}{l}\text { There is one sarcophagus of Type I. Dating was } \\
\text { not provided by İdil (İdil 1993, } 74 \text {, Kat. 1, Lev. } \\
\text { 74, 4). In my opinion this sarcophagus can be } \\
\text { dated to between the Hellenistic and, at the } \\
\text { latest, the start of the It }{ }^{\text {st }} \text { c. A.D. }\end{array}$ \\
\hline Besik ören & Simple. & $\begin{array}{l}\text { Aktan doesn't suggest a date for this sarcophagus } \\
\text { (Aktan 2000, 151, Res. 29), but it is of Type I, } \\
\text { hence we dated to between the Hellenistic and the } \\
\text { beginning of the I } \mathrm{I}^{\text {st }} \text { c. A.D. }(\mathrm{Pl} . \mathrm{V}, 1) \text {. }\end{array}$ \\
\hline $\begin{array}{l}\text { Xanthos } \\
\text { Ahquadi } \\
\text { Sarcophagus }\end{array}$ & Lion protoms. & $\begin{array}{l}\text { Hellenistic. Lycian inscription (Metzger, } 1969 \text {, } \\
\text { 225-232; İdil, 1993, 85, Kat. 5). There are two } \\
\text { solid blocks above the hyposorion, reminding as a } \\
\text { form much more to the shapes of the sarcophagi }\end{array}$ \\
\hline
\end{tabular}




\begin{tabular}{|c|c|c|}
\hline & & $\begin{array}{l}\text { of the } I V^{\text {th }} c . \text { B.C. Consequently to be dated to } \\
\text { between the end of the } I^{\text {th }} \text { c. B.C. and the early } \\
\text { Hellenistic period. }\end{array}$ \\
\hline $\begin{array}{l}\text { Xanthos Pillar } \\
\text { sarcophagus }\end{array}$ & Simple. & $\begin{array}{l}\text { Hellenistic (Demargne-Metzger 1967, } 1375- \\
\text { 1408, 1394; İdil, 1993, 86, Kat. 8) (The second } \\
\text { decade of } \text { III }^{\text {rd }} \text { c. B.C.). Demargne-Metzger dated } \\
\text { this sarcophagus from the portrait of Berenice } \\
\text { Euergetes who was depicted on the oinoche } \\
\text { found in the grave (Demargne-Metzger 1967, } \\
\text { 1394). However, we consider this date too late } \\
\text { and an earlier date is more appropriate than the } \\
\text { second decade of the III }{ }^{\text {rd }} c \text {. B.C. The oinoche } \\
\text { probably comes from the later use of this sar- } \\
\text { cophagus. In my opinion it is to be dated between } \\
\text { the end of the IV }{ }^{\text {th }} \text { c. and beginning of the III }{ }^{\text {rd }} \mathrm{c} \text {. } \\
\text { B.C. for the Pillar sarcophagus in Xanthos (Pl. V, } \\
\text { 2). }\end{array}$ \\
\hline Isinda & Simple. & $\begin{array}{l}\text { There are three sarcophagi in Isinda. According } \\
\text { to İdil (İdil 1993, 36, Kat. 1-3), dating from the } \\
\text { III }^{\text {rd }} \text { c. A.D., in my opinion, they are of Type I } \\
\text { and hence date at the latest from the }{ }^{\text {st }} \text { c. A.D. }\end{array}$ \\
\hline \multicolumn{3}{|l|}{ Type II } \\
\hline City & Ornament & Date \\
\hline Cyaneai & $\begin{array}{l}\text { Lion protomes, mask, pilasters } \\
\text { on the corner of the chest, } \\
\text { rosette motifs (above the pilas- } \\
\text { ters). }\end{array}$ & $\begin{array}{l}\text { There are fifteen sarcophagi of Type II at } \\
\text { Cyaneai (Ugurlu 1999, 70, Kat. 28-9, 30-7, } 42-6 \text {, } \\
59,60-5,71-77 \text { ). Type II began in the late } \mathrm{I}^{\text {st }} \text { c. } \\
\text { A.D. but increased gradually in the beginning } \\
\text { and middle of the II }{ }^{\text {nd }} \text { C. A.D. in Cyaneai. The } \\
\text { sarcophagi without pilasters are dated to that } \\
\text { period. The production of the sarcophagi with } \\
\text { pilasters began in Cyaneai from the middle of } \\
\text { the } \text { II }^{\text {nd }} \text { c. A.D. (Pl. VI, 1). }\end{array}$ \\
\hline Arycanda & Bull heads. & $\begin{array}{l}\text { Dated to the } \mathrm{I}^{\mathrm{st}} \mathrm{c} \text {. A.D. (Idil 1993, 31, Kat. 8). We } \\
\text { suggest the end of } \mathrm{I}^{\text {st }} \text { c. A.D. as this type began in } \\
\text { the late } \mathrm{I}^{\text {st }} \text { c. A.D. (Pl. VI, 2). }\end{array}$ \\
\hline Tlos & Simple. & $\begin{array}{l}\text { There are three sarcophagi of Type II. İdil } \\
\text { suggested the Roman period (İdil 1993, Kat. 3- } \\
\text { 7), As they are without pilasters, they can be } \\
\text { dated to between the beginning and the middle } \\
\text { of the } \text { II }^{\text {nd }} \text { c. A.D. }\end{array}$ \\
\hline Hoyran & Simple. & $\begin{array}{l}\text { İdil suggested the Roman period (İdil } 1993,35 \text {, } \\
\text { Kat. } 4 \text {; Levie } 1982,42 \text { ). The absence of pilasters on } \\
\text { the chest should date it to the middle of the } \operatorname{II}^{\text {nd }} \text { c. } \\
\text { A.D. The absence or presence of pilasters pro- }\end{array}$ \\
\hline
\end{tabular}




\begin{tabular}{|c|c|c|}
\hline & & vides a significant element in dating sarcophagi. \\
\hline Andriace & Simple. & $\begin{array}{l}\text { According to İdil dating from the } \mathrm{I}^{\mathrm{st}} \text { or } \mathrm{II}^{\mathrm{nd}} \text { c. A.D. } \\
\text { (İdil 1993, 24, Kat. 6). In my opinion (Uğurlu } \\
\text { 2003,363, Cat. 39), this sarcophagus is an early } \\
\text { example of Type II and can be dated to between } \\
\text { the end of } \mathrm{I}^{\mathrm{tt}} \text { and the beginning of the } \mathrm{II}^{\text {nd }} \text { c. A.D. }\end{array}$ \\
\hline \multicolumn{3}{|l|}{ Type III } \\
\hline City & Ornament & Date \\
\hline Cyaneai & $\begin{array}{l}\text { Without ornament on the lid. } \\
\text { Corner pilasters are on the } \\
\text { chests. }\end{array}$ & $\begin{array}{l}\text { There are twenty-nine sarcophagi of Type III in } \\
\text { Cyaneai (Uğurlu 1999, 73, Kat. 3-7, 10-19, } 24 \text {, } \\
\text { 34-8, 40-5, 57, } 73 \text { (The sarcophagi with pilasters } \\
\text { are: Kat. 23, 32-3, 35-6, 64-9). Analyzing from } \\
\text { the inscriptions on the sarcophagi, they seem to } \\
\text { have started in the } \mathrm{I}^{\text {st }} \text { c. A.D., gradually increased } \\
\text { to the middle of } \mathrm{II}^{\text {nd }} \text { c. A.D. The examples with } \\
\text { pilasters date from after the middle of the } \mathrm{II}^{\text {nd }} \text { c. } \\
\text { A.D. with Type III continued into III }{ }^{\text {rd }} \text { c. A.D. } \\
(\mathrm{Pl} \text {. VII, 1). }\end{array}$ \\
\hline Ulupınar-Belen & $\begin{array}{l}\text { Bull head, women portrait and } \\
\text { Eros figures. }\end{array}$ & $\begin{array}{l}\text { İdil suggested the Roman period (İdil 1993, } 81 \text {, } \\
\text { Kat. 1). On Lycian sarcophagi, Eros figures are } \\
\text { generally depicted on those sarcophagi of Type } \\
\text { IV. However these sarcophagi began to be } \\
\text { produced a little later than the middle of the II }{ }^{\text {nd }} \\
\text { c. A.D. It is also noted that the lid lacks a cassette } \\
\text { band, found in later period of Type III. Conse- } \\
\text { quently, we suggest it dates from the middle to } \\
\text { the end of the II }{ }^{\text {nd }} \text { c. A.D. }\end{array}$ \\
\hline Andriace & Simple. & $\begin{array}{l}\text { There are five sarcophagi of Type III at Andri- } \\
\text { ace. According to İdil dating from the } \text { II }^{\text {nd }} \text { c. } \\
\text { A.D. (İdil } 1993,22, \text { Kat. 1-2, 5). In my opinion, a } \\
\text { date between the start and the middle of the II }{ }^{\text {nd }} \\
\text { c. A.D is apt as they are comparable with } \\
\text { examples without pilasters of Type III (Uğurlu } \\
\text { 2003, 359, Cat. 30-1). }\end{array}$ \\
\hline Arycanda & Simple. & $\begin{array}{l}\text { III }{ }^{\text {rd }} \text { c. A.D. (İdil } 1993,28 \text {, Kat. 2-6). There are } \\
\text { two sarcophagi of Type III at Arycanda (Pl. VII, } \\
\text { 2). }\end{array}$ \\
\hline Rhodiapolis & Simple. & III ${ }^{\text {rd }}$ c. A.D. ( İdil 1993, 63, Kat. 2). \\
\hline Tlos & Simple. & $\begin{array}{l}\text { There are two sarcophagi of Type III at Tlos. İdil } \\
\text { suggested the III }{ }^{\text {rd }} \text { c. A.D. (İdil 1993, 77, Kat. 7-8). } \\
\text { Only one band on the short sides of the lid } \\
\text { belongs to the earlier examples of Type III. The } \\
\text { lid examples with hemispherical projections are } \\
\text { found much more frequently from the end of the }\end{array}$ \\
\hline
\end{tabular}


$\mathrm{II}^{\text {nd }}$ and the III $^{\text {rd }}$ century A.D., supported by examples with inscriptions from Cyaneai.

\section{Type IV}

$\begin{array}{ll}\text { City } & \text { Ornament } \\ \text { Cyaneai } & \text { Lion protomes, Medusa heads, } \\ & \text { palmetto motifs on the acroteria, } \\ & \text { spiral motif, pseudo roof tile, } \\ & \text { Eros figure on the lids. With/ } \\ & \text { without grooved corner pilasters } \\ & \text { on the chests, Putti who hang to } \\ \text { the tabula ansate, man and wo- } & \\ \text { men figures stand on the short } \\ \text { sides of the chests. }\end{array}$

\section{Date}

\begin{tabular}{|c|c|c|}
\hline Andriace & $\begin{array}{l}\text { Medusa heads, imitation roof } \\
\text { tiles on the lids, corner pilasters } \\
\text { on the chest, rosette motifs, } \\
\text { man who stands and holds a } \\
\text { wreath on the short side. }\end{array}$ & $\begin{array}{l}\text { There are four sarcophagi of Type IV in } \\
\text { Andriace. İdil suggested the last quarter of the II }{ }^{\text {nd }} \\
\text { c. A.D. for two of them (İdil 1993, 25, Cat. 8-9). } \\
\text { One of them is dated to the last quarter of the II }{ }^{\text {nd }} \\
\text { c. A.D. by Wiegartz (Wiegartz 1965, 74, Fig. } 46 \text { A). } \\
\text { Ugurlu dated them between the last quarter of the } \\
\text { II }^{\text {nd }} \text { c. and the early III }{ }^{\text {rd }} \text { c. A.D. (Ugurlu 2003, 357, } \\
\text { Cat. 9, 16, 52, 67), (Pl. VIII, 2). }\end{array}$ \\
\hline Patara & Simple. & $\begin{array}{l}\text { There are two sarcophagi of Type IV at Patara. } \\
\text { İdil suggested Roman period date (İdil 1993, } 52 \text {, } \\
\text { Kat. 3-4). In my opinion, from the absence of } \\
\text { pilasters examples on Type IV sarcophagi, these } \\
\text { can be dated from the middle of the } \text { II }^{\text {nd }} \text { to the } \\
\text { early } I I I^{\text {rd }} \text { c. A.D. }\end{array}$ \\
\hline Pinara & Simple. & $\begin{array}{l}\text { İdil dated it to the Roman Period (Idil } 1993,62 \text {, } \\
\text { Kat. 5). The sarcophagus lacking pilasters is of } \\
\text { Type IV, hence we can date it at the earliest to } \\
\text { the middle of the IIn }{ }^{\text {nd }} \text { c. A.D. and at the latest to } \\
\text { the III }{ }^{\text {rd }} \text { c. A.D. }\end{array}$ \\
\hline Sidyma & $\begin{array}{l}\text { Small shield (or rosette), Eros } \\
\text { figure, Medusa Head. }\end{array}$ & $\begin{array}{l}\text { There are six sarcophagi of Type IV in Sidyma. } \\
\text { Two of them are dated to the period of Antonius } \\
\text { Pius (İdil 1993, 64, Kat. 1 A-B), (A.D.138-161); } \\
\text { the others are dated to the beginning of the III }{ }^{\text {rd }} \text { c. } \\
\text { A.D. by İdil (İdil 1993, Kat. 2-5). The examples } \\
\text { without pilasters, as is understood from their } \\
\text { inscriptions, are similar to the dates that we } \\
\text { suggested as dates for the Type IV. The lid with } \\
\text { the Eros figure and Medusa is dated to between } \\
\text { the middle and the last quarter of the } \text { II }^{\text {nd }} \text { c. A.D. } \\
\text { The latest date could be the beginning of the III } \\
\text { c. A.D. }\end{array}$ \\
\hline
\end{tabular}




\begin{tabular}{|ll}
\hline Oinoanda & Wreaths, Medusa head, open \\
& $\begin{array}{l}\text { hand (palm) motif, palmetto are } \\
\text { carved on the lid. }\end{array}$
\end{tabular}

There are four sarcophagi of Type IV in Oinoanda. İdil dated them to between the end of the II $^{\text {nd }} \mathrm{c}$. and the start of the III ${ }^{\text {rd }} \mathrm{c}$. A.D. (Iddil 1993, 47, Kat. 1-4). We consider they were produced between the mid and last quarter of the $I^{\text {nd }}$ c. A.D. When we compared the motifs to those found in other cities, we find these motifs are repeatedly employed during this period.

Tlos

Lying winged Eros, Medusa head carved on the lid.

İdil dated to the II $^{\text {nd }}$ or III ${ }^{\text {rd }}$ c. A.D. (İdil 1993, 79, Cat. 10). The sarcophagi with Eros figures of Type IV seem to have been produced between middle and last quarter of the $\mathrm{IId}^{\text {nd }}$ c. A.D. The export sarcophagi which appeared after the middle of the II ${ }^{\text {nd }}$ c. A.D. (continued from the third quarter of the I $^{\text {nd }} c$ c. A.D.) were influenced by such local sarcophagi in Lycia. We observed and surveyed from publications, the export sarcophagi that were generally produced from the mid to the fourth quarter of the $\mathrm{II}^{\text {nd }}$ c. A.D.

\section{Type IV Export Sarcophagi}

\begin{tabular}{|c|c|c|}
\hline City & Ornament & Date \\
\hline Limyra & $\begin{array}{l}\text { Attic lid fragment (imitation ro- } \\
\text { of tile motifs), Palmetto, shield, } \\
\text { acanthus folios frieze. }\end{array}$ & $\begin{array}{l}\text { The third quarter of } \text { II }^{\text {nd }} \text { c. A.D. (Peschlow 1974, } \\
\text { 225-31, 227, n. 8, Abb. 3). }\end{array}$ \\
\hline Limyra & $\begin{array}{l}\text { The Garland sarcophagus (Pro- } \\
\text { connessos marble). The sarco- } \\
\text { phagus of the Gymnasiarch. } \\
\text { Hermes and Heracles busts are } \\
\text { among the garlands on the front } \\
\text { of the chest. Nike figures on the } \\
\text { corners. Eros figures are on the } \\
\text { postament. Omphalos plate, } \\
\text { Medusa head. Imitation roof } \\
\text { tiles, flower motif, Eros figure on } \\
\text { the acroteria (on lid). }\end{array}$ & $\begin{array}{l}\text { The third quarter of the III }{ }^{\text {rd }} \text { c. A.D. (A.D.170- } \\
\text { 180) Hanel 1985, 177-210, 177, 207-8, Abb. 3- } \\
\text { 13; Hanel 1999, 109, Pl. 66) }\end{array}$ \\
\hline Andriace & $\begin{array}{l}\text { Medusa head (Docimeion } \\
\text { marble?). }\end{array}$ & $\begin{array}{l}\text { The late II }{ }^{\text {nd }} \text { - early III }{ }^{\text {rd }} \text { c. A.D. (Uğurlu, 2003, } \\
\text { 366, Cat. 52, Fig. 14). }\end{array}$ \\
\hline Patara & $\begin{array}{l}\text { Lion head, palmetto motifs on } \\
\text { the corner acroteria, rosette } \\
\text { motif, lotus-palmetto, egg pear } \\
\text { rank and Lesbian cymation. }\end{array}$ & $\begin{array}{l}\text { Bulut-Gulsen put it into the Pamphylian Type } \\
\text { and dated to the Late Antonine Dynasts (Bulut- } \\
\text { Gülşen } 1998,189-203,190 \text {, Fig. 4-6). We concur } \\
\text { with this Late Antoninus period date. Although } \\
\text { export sarcophagi began to appear from the } \\
\text { middle of the } \mathrm{II}^{\text {nd }} \text { c. A.D. (A sarcophagus found in } \\
\text { Lydai is dated about } 155 \text { A.D.: Rodenwaldt } 1933 \text {, }\end{array}$ \\
\hline
\end{tabular}




\begin{tabular}{|c|c|c|}
\hline & & $\begin{array}{l}\text { 181-213, 205; Wiegartz } 1965,164 \text {, Taf. } 40 \mathrm{f}-1 \mathrm{c}-\mathrm{d} \text { ) } \\
\text { A.D., the demand increased in the last quarter of } \\
\text { the } \mathrm{II}^{\text {nd }} \text { and the } \mathrm{III}^{\text {rd }} \text { c. A.D. }\end{array}$ \\
\hline Xanthos & $\begin{array}{l}\text { Attic, Eros sarcophagus. } \\
\text { Imitation roof tiles, egg pear } \\
\text { rank, and narrow Lesbian } \\
\text { cymation. }\end{array}$ & $\begin{array}{l}\text { Rodenwaldt dated it to the last quarter of the II } \\
\text { c. century A.D. (Rodenwaldt } 1933,184,211, \mathrm{Pl} \text {. } \\
\text { X, fig. 3-4). Koch-Sichterman suggested 150- } \\
175 \text { A.D. (Koch-Sichterman 1982, 476-92). } \\
\text { Wiegartz dated it to about } 200 \text { A.D. (Wiegartz } \\
\text { 1965, 177). Walker-Coleman, gave it to the early } \\
\text { III }^{\text {rd }} \text { c. A.D. (Walker-Coleman, 1993, 169-75, } \\
\text { 174-5, Taf. 8). According to Walker-Coleman } \\
\text { Attic sarcophagi were obtaining a share of the } \\
\text { Lycia market in the early } \text { III }^{\text {rd }} \text { c. A.D. (Walker- } \\
\text { Coleman, 1993, 175). }\end{array}$ \\
\hline \multicolumn{3}{|l|}{ Type V } \\
\hline City & Ornament & Date \\
\hline Cyaneai & $\begin{array}{l}\text { Medusa head, pilasters on the } \\
\text { chests, Putti who hang from the } \\
\text { tabula ansate, garland, portrait } \\
\text { busts, shield. }\end{array}$ & $\begin{array}{l}\text { There are four sarcophagi of Type V in Cyaneai. } \\
\text { Ugurlu suggested 170/80-200 A.D. (Ugurlu } \\
\text { 1999, 81, Kat. 22, 43,63,75). We consider Type } \\
\text { V, like Type IV, began to be produced in the } \\
\text { region after the middle of the } \text { I }^{\text {nd }} \text { c. A.D. and } \\
\text { continued in the III }{ }^{\text {rd }} \text { c. A.D. Supported by } \\
\text { examples with inscriptions; it is possible to say } \\
\text { type V was not produced in the }{ }^{\text {st }} \text { c. A.D. (Pl. IX, } \\
\text { 1). }\end{array}$ \\
\hline Idebessos & Shield & $\begin{array}{l}\text { Kupke gave a photo but no date (Kupke, } 1989,4 \text {, } \\
\text { Res. 4). However it was produced at the earliest } \\
\text { in the middle of the II }{ }^{\text {nd }} \text { c. A.D. and, at the latest, } \\
\text { in the III }{ }^{\text {rd }} \text { c. A.D. It carries motifs similar to the } \\
\text { examples from Cyaneai and of Type V. }\end{array}$ \\
\hline Beycik-Basoren & Simple & $\begin{array}{l}\text { Aktan gave a photo but no date (Aktan } 2000 \text {, } \\
\text { Res. } 21 \mathrm{~A} / \mathrm{B} .-\mathrm{C} \text { ). It can be dated to between the } \\
\text { middle of the } \mathrm{II}^{\text {nd }} \text { and the } \mathrm{III}^{\text {rd }} \text { c. A.D. }\end{array}$ \\
\hline Nisa & Shield & $\begin{array}{l}\text { Bean gave a photo but no date (Bean } 1997,165 \text {, } \\
\mathrm{Pl} .90 \text { ). We can date it to between the middle of } \\
\text { the } \mathrm{II}^{\text {nd }} \text { and the } \mathrm{III}^{\text {rd }} \text { c. A.D. }\end{array}$ \\
\hline
\end{tabular}




\section{BIBLIOGRA PHY}

Aktan - Aktan 2000

Akurgal 1961

Atilla 1981

Bean 1997

Benndorf - Niemann 1975

Borchhardt - Neumann 1997

Borchhardt 1975

Bulut - Gülşen

Demargne - Metzger 1967

Hanel 1985

Hanel 1999

İdil 1993

Kjeldsen - Zahle 1975

Kleiner 1957

Koch - Sichterman 1982

Kupke 1989

Levie 1982

Metzger 1969

Peschlow 1974

Rodenwaldt 1933

Şanlı 1996

Uğurlu 1999

Uğurlu 2003

Walker - Coleman 1993

Wiegartz 1965

Yılmaz 1994

Zahle 1979
H. Aktan - O. Aktan, Olympos ve Khimaira, Doğu Likya'nın Dünü ve Bugünü. Ankara 2000.

E. Akurgal, Die Kunst Anatoliens von Homer bis Alexander. Berlin 1961.

İ. A. Atilla, "Likya Lahitleri". Arkeoloji ve Sanat Dergisi 8/9 (1981) 21-28.

G. Bean, Eskiçağda Lykia Bölgesi. Çev.: H. Kökten. İstanbul 1997.

O. Benndorf - G. Niemann, Das Heroon von Gjölbashi. Wien 1889.

J. Borchhardt - G. Neumann, "Die Grabstifung des xudara in der westlichen von Limyra”. ÖJh 66 (1997) 63-74.

J. Borchhardt, "Myra Ein Lykische Metropole in Antiker und Byzantiner Zeit". IstForsch 30 (1975) 254-286.

S. Bulut - F. Gülşen, "Patara-Bodrum Gömütü”. Adalya II (1998) 189-203.

P. Demargne - H. Metzger, "Xanthos in Lykien". RE IX A/2 (1967) 1375-1408.

A. Hanel, "Ein Marmor-Girlanden-Sarkophag aus Limyra". ÖJh 56 (1985) 177-210.

A. Hanel, "Bir Gymnasion Başkanının Girlandlı Lahdi". Ed. J. Borchhardt, Limyra Zemuri Taşları. Çev.: G. Yümer. İstanbul (1999) 109. V. İdil, Likya Lahitleri. Ankara 1993.

K. Kjeldsen - J. Zahle, "Lykische Graber - Ein vorlaufiger Bericht". AA (1975) 312-350.

G. Kleiner, "Hellenistische Sarkophage in Kleinasien". IsttMitt 7 (1957) $1-10$.

G. Koch - H. Sichterman, "Römische Sarkophage". HdArch (1982) 476-492.

B. Kupke, "Siedlung und Nekropolen". Antike Welt 20 (1989) 32-58.

C. D. Levie, Les Piliersfunéraires de Lycie. Louvain 1982.

H. Metzger, "Reliefs inédits de Xanthos". RA (1969) 225-232.

U. Peschlow, "Fragmente eines Heiligen sarkophages in Myra". IstMitt 23/24 (1973/1974) 225-231.

G. Rodenwaldt, "Sarcophagi from Xanthos". JHS 53 (1933) 181-213.

A. Şanlı, "Die Hangsiedlung von Büyük Avşar". LykischeStudien 2 (Hv. F. Kolb) (1996) 153-185.

E. Uğurlu, Kyaneai Bezeme ve Yazttl Lahitleri. Yayımlanmamış Yüksek Lisans Tezi, Ankara Üniversitesi. Ankara 1999.

E. Uğurlu, "Sarcophagi in the Necropoleis of Andriake, Near Myra (Lycia)". JRA 16 (2003) 355-366.

S. Walker - M. L. Coleman "Roman Sarcophagi from Lycia in the British Museum Collections". Tituli Asia Minoris 7. 1 (1993) 169-175.

H. Wiegartz, Kleinasiatischen Säulen sarkophage, Untersuchungen zum Sarkophagtypus und zu den figürlichen Darstellungen. Berlin 1965.

H. Yılmaz, "Überlegungen zur Typologie der Lykischen Sarkophage". Likya I (1994) 42-48.

J. Zahle, "Lykische Felsgrabermit Reliefs aus dem 4.jh.v. Chr. - Neue und Alte Funde". JdI 94 (1979) 245-346. 